\title{
TO QUESTION REGENERATION OF SORBENTS, USED FOR PURIFICATION OF ALKYLATES FROM ADMIXTURES OF ALUMINIUM CHLORIDE, HYDROCHLORIDE AND HEAVY RESIDUES \\ Amirov F.A. ${ }^{1}$, Shakhverdiyeva F.M. ${ }^{2}$, Sultanova G.Dj. ${ }^{3}$ Email: Amirov630@scientifictext.ru
}

\author{
${ }^{1}$ Amirov Fariz Ali oglu - Doctor of technical sciences, Professor, Chief of Department; \\ ${ }^{2}$ Shakhverdiyeva Fatima Maqomed qizi - Associate Professor, \\ DEPARTMENT OF TECHNOLOGY OF ORGANIC AND HIGH MOLECULAR COMPOUNDS; \\ ${ }^{3}$ Sultanova Gulnara Djamil qizi - Associate Professor, \\ DEPARTMENT OF PETROCHEMICAL TECHNOLOGY AND INDUSTRIAL ECOLOGY, \\ FACULTY OF CHEMICAL TECHNOLOGY, \\ AZERBAIJAN STATE UNIVERSITY OF OIL AND TECHNOLOGY, \\ BAKU, REPUBLIC OF AZERBAIJAN
}

\begin{abstract}
: in given research the results regeneration of solid sorbent, which are used for purification of alkylates, received by alkylation of benzene by high olefines in presence of aluminium chloride are given.

The admixtures contain aluminium chloride, hydrochloride and residues of highmolecular hydrocarbons. Regeneration of sorbents is concluded in hydrolysis of aluminium chloride by superheated steam and oxidative regeneration, by which the burning out of organic residues and dehydration of hydrolysis products take place. By that the main goal of investigation is achieved-to replace the traditional water-alkaline washing of alkylate by "dry" adsorptive purification, don t-giving the ecologically harmful water-alkaline wates and increasing the technical-economical indices of high alkylbenzenes production in presence of catalyst aluminium chloride.

Keywords: regeneration, adsorbents, aliminium chloride, hydrochloride, water steam.

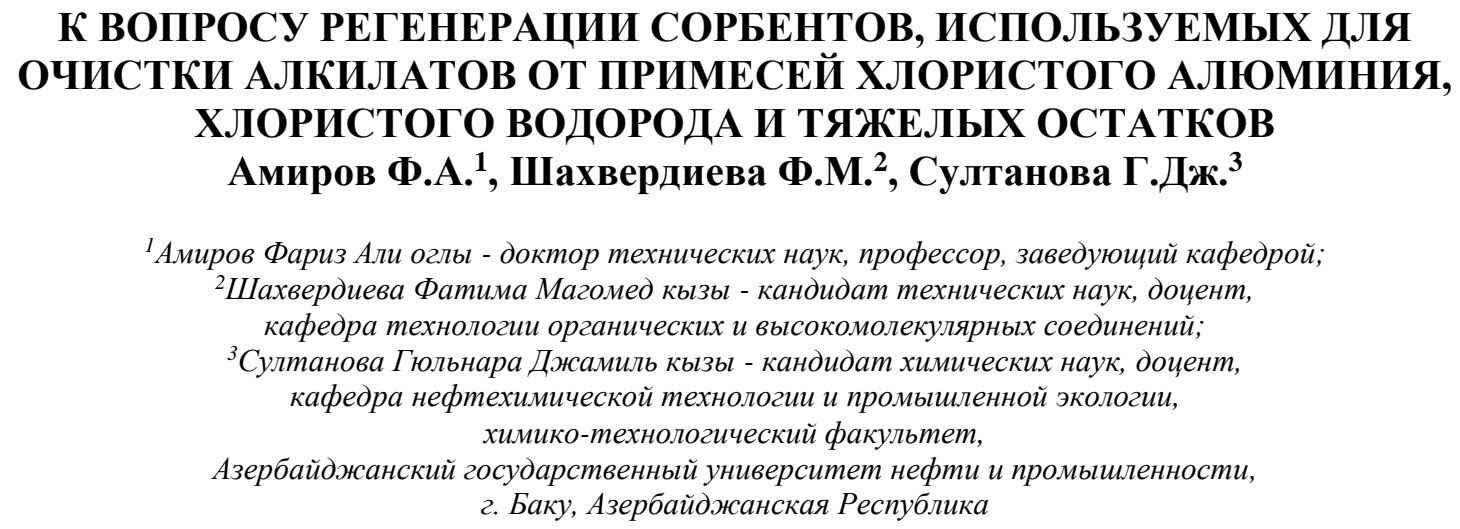

\begin{abstract}
Аннотация: в данных исследованиях приводятся результаты регенерации твердых сорбентов, используемых для очистки алкилатов, полученных при алкилировании бензола высшими олефинами $в$ присутствии хлористого алюминия.

Примеси содержат хлористый алюминий, хлористый водород и остаток высокомолекулярных углеводородов. Регенеращия состоит в гидролизе хлористого алюминия перегретым водяным паром и окислительной регенерации, при которой происходит выжиг остатков органики и дегидротация продуктов гидролиза, при котором достигается основная иеель исследований - заменить традиционную водно-щелочную отмывку алкилата «сухой» адсорбционной очисткой, не дающей экологически вредных водно-щелочных стоков и повышающей технико-экономические показатели производства высших алкилбензолов в присутствии катализатора хлористого алюминия.
\end{abstract}

Ключевые слова: регенерация, адсорбенты, хлористый алюминий, хлористый водород, водяной пар.

UDC 66.021.2.0.81.3

At present time research and development of the new technological processes production of alkylbenzenes is realized in two direction: creation of new technological schemes by use of highactive selective and stable catalysts and improvement of processes by use of Aluminium chloride. Aluminium chloride display a high catalytic activity in reaction transalkylation of polyalkylbenzenes which leads to increase of monoalkylbenzenes yield.

The given work is continuation of research, conducted by us by purification from admixtures, containing in alkylate by adsorbtive parification of alkylate with solid sorbents. In the works [1, 2] the investigations by adsorptive purification of alkylate, presenting itself the plant sample, received by alkylation of benzene by 
chloroparaffines in presence of $\mathrm{AlCl}_{3}$ (one of the stage production of sulphonol on production accociation "Khimprom", Sumqayit city are presented). As adsorbents the aluminium oxide, mordenite, clinoptilolyte, zeolitecontaining Seokar 3. have been investigated.

The possibility of adsorptive "dry" purification of alkylate, deprivated shortages of traditional water-alkaline processing.

At present work the investigation by regeneration of adsorbents are presented.

In process of adsorption the sorbent (any from researehed by us) is saturated by admixtures of aluminium chloride, hydrochloride and residues of highmolecular hydrocarbons that is determined by overshoot $\mathrm{o}$ admixtures in selected samples and therefore the adsorption plant in transfered on regim of regeneration. For removal of alkylaromatic hydrocarbons, adsorbed on surface of adsorbent the method of displacement desorption with help of solvent have been used.

As solvent the benzene have been used. After hydrocarbons desorption the temperature in adsorber was increasing up to $115-120^{\circ}$ for distillation of solvent from sorbent surface. Then the adsorbtive column-adsorber (1) was carryng on regeneration plant, presented on illustration 1 . By temperature $120^{\circ} \mathrm{C}$ the air was giving in system by microcompressor 2 .

After acivement of temperature in column equal $150 \mathrm{C}$ in evaporator 4 by syringe-dozator with constant rate the distillated water was giving. The air-vapour mixture from evaporator 4 was giving in adsorbtive column 1.

By giving of dry air by temperature $180-200^{\circ} \mathrm{C}$ a sublimation of aluminium chloride is observed and it is crystallized on walls of tubes from furnace until condensator-catcher 5 . Therefore the adsorbed aluminium chloride is partly hydrolized by temperature $120-150^{\circ} \mathrm{C}$ (no lower for prevention of water vapour condensation in sorbent). By that the forming aluminium hydrochlorides present itself volatile compounds. Subsequent heating of saturated by admixtures sorbent under flow of moist air by temperature $450-650^{\circ} \mathrm{C}$ leads to complete decomposition of adsorbed aluminium chloride by separation of three molecules of hydrochloride on mole of $\mathrm{AlCl}_{3}$ and complete burn-out of formed in reaction highmolecular compounds. The following reaction proceeds:

$$
2 \mathrm{AlCl}_{3}+3 \mathrm{H}_{2} \mathrm{O} \rightarrow \mathrm{Al}_{2} \mathrm{O}_{3}+6 \mathrm{HCl}
$$

The formed aluminium oxide is combined with sorbent surface and alminium chloride with exhaust air is received in condensator-catcher 5 . Hydrochloride is absorbed in absorber 7 by water and inert gases over foamer 8 are thrown in atmosphere.

Because of investigated sorbents such as clinoptilolyte, seokar-3 consist from aluminium oxides and silicon, the regeneration reactions may be presented by the folowing scheme.

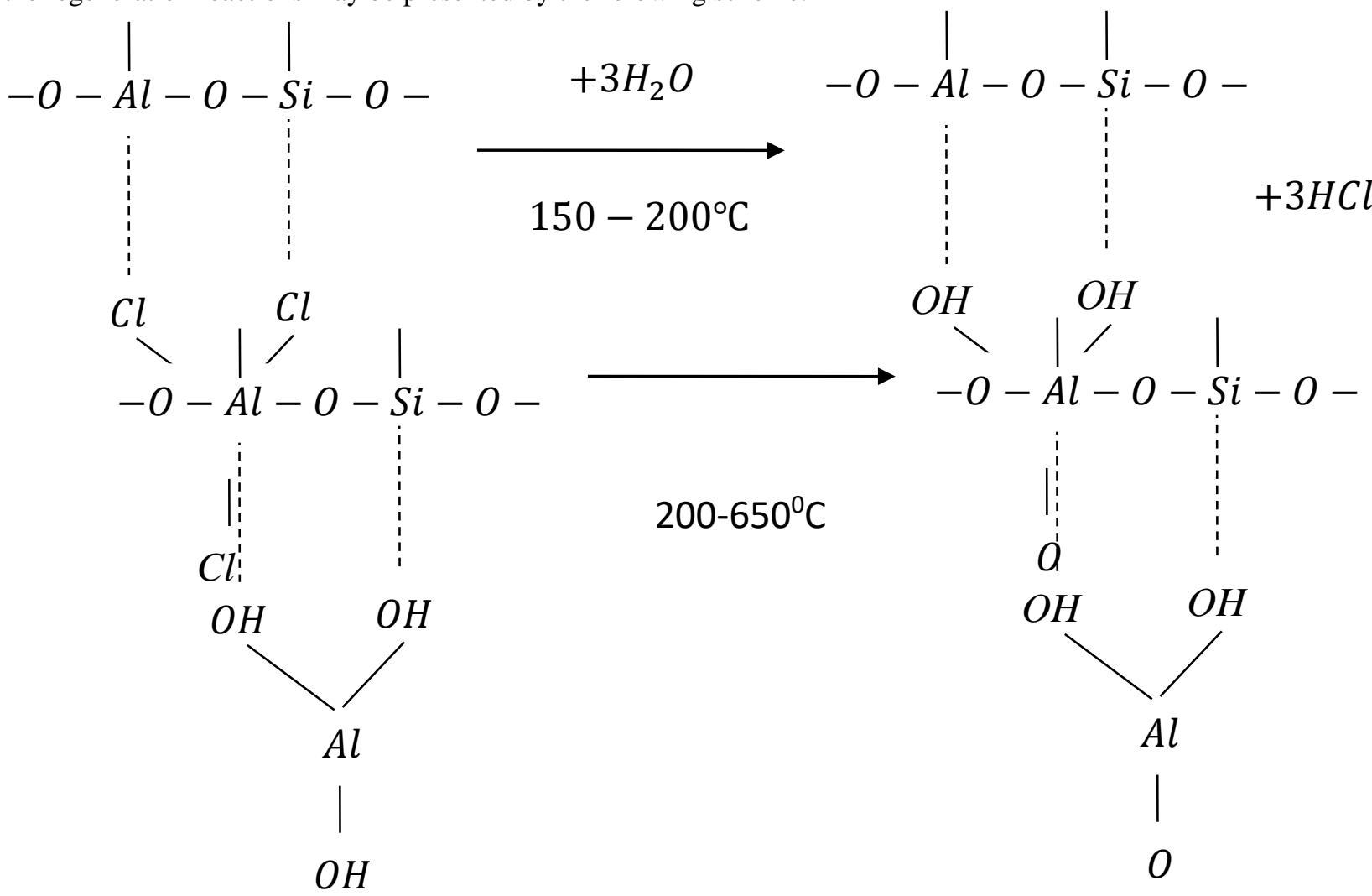

By described method the repeated saturation-regeneration of adsorbents have been realized: aluminium oxide, clinoptilolyte, Seokar-3. 
Thus, regeneration of sorbent from aluminium chloride, hydrochloride and heavy residue of organic compounds, consist in hydrolysis of aluminium chloride by overheated water steam and oxidative regeneration, by which a burn-out of organic residues and dehydration of hydrolysis products take place.

After of enough big amount of cycles "adsorption-regeneration" the surface layer of adsorbent will present itself the initial core of sorbent with combined second surface of aluminium oxide.

In present work the dependence of decomposition rate of adsorbed aluminium chloride from rate giving of water steam by temperature $200 \mathrm{C}$ have been studied. As the example, one of the large experiments, conducted on clinophlolyte, modified by $0,1 \mathrm{~N} \mathrm{HCl}$ is shown [3].

Over adsorption column 1 (illustration 1) filled up by modified clinoptilolite in amount 2 gram the alkylate, containing admixture of aluminium chloride by 0,4694 mas. concentration is put. After 240 minutes of alkylate put, the selected sample shown the overshoot of aluminium chloride. Coming from that in alkylate the concentration of aluminium chloride makes up 0,469\% mas. the amount of adsorbed aluminium chloride have been calculated

$$
\frac{0,18 \cdot 0,469 \cdot 240}{100}=0,2 \mathrm{~g} \mathrm{AlCl}_{3}
$$

Taking into consideration that alkylate was crossing over adsorbent until receive of equilibrium concentration, the adsorbent adsorbed one more 0,01 gram of $\mathrm{AlCl}_{3}$.

In all amount of adsorbed aluminium chloride made up 0,21 gram. By that the rate feed of water steam was changing from 7,3 mole/mol of $\mathrm{AlCl}_{3}$ in hour up to $11,3 \mathrm{~mole} / \mathrm{mole}$ air equal $3 \mathrm{l} / \mathrm{hour}$.

In the table 1 data, showed the dependence of rate decomposition of aluminium chloride from rate feed of water steam are persented. The hydrochloride, separating by decomposition of aluminium chloride was caught in receiver 7 and was titrated by alkali, determing by that the amount of hydrochloride. By reaction decomposition of aluminium chloride in presence of water steam the theoretical yield of hydrochloride in calculation on 0,21 gramm of aluminium chlride make up 0,712 gram. 


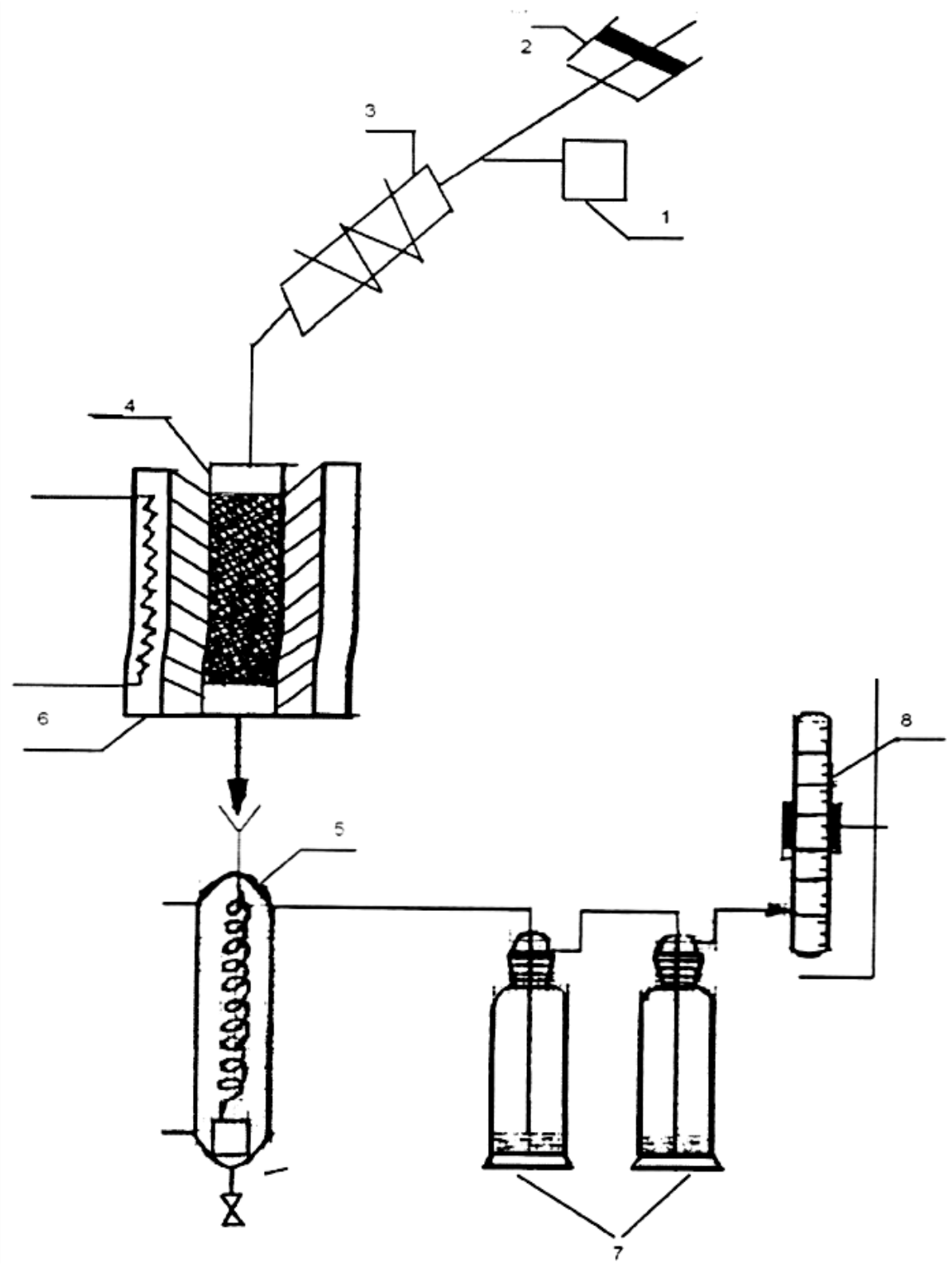

Fig. 1. Plant of investigation of sorbent regeneration: 1 - microcompressor, 2 - syringe-meter, - evaporator, 4 - adsorber, 5 condensator-catcher, 6 - furnace, 7 - absorbers, 8-foam apparatus

Table 1. Dependence of decomposition rate of adsorbed aluminium choride from rate feed of water steam

\begin{tabular}{|c|c|c|c|c|}
\hline Temperature & $\begin{array}{c}\text { Rate feed of water } \\
\text { steam }\end{array}$ & $\begin{array}{c}\text { Time of feed of } \\
\text { water steam }\end{array}$ & $\begin{array}{c}\text { Amount of HCl, } \\
\text { used on titration }\end{array}$ & $\begin{array}{c}\text { Yield of } \\
\text { decomposed AlCl } \mathbf{3}\end{array}$ \\
\hline${ }^{0} \mathrm{C}$ & Mole/mole & Minute & Gram & $\begin{array}{c}\% \text { from theoretical } \\
\text { possible }\end{array}$ \\
\hline 200 & 7,3 & 60 & 0,123 & 71,5 \\
\hline 200 & 9,3 & 60 & 0,139 & 80,81 \\
\hline 200 & 11,3 & 60 & 0,148 & 86,1 \\
\hline
\end{tabular}

As it is evident from data of the table 1, the rate decomposition of aluminium chloride in given interval essentially depend on rate feed of water steam. So, by rate of water steam feed equal 7,3 mole/ mole $\mathrm{AlCl}_{3} \cdot$ hour, decomposition of aluminium chloride on 60 minutes take place on $71,5 \%$. Rise of rate of water steam feed up to $11,3 \mathrm{~mole} / \mathrm{mole} \mathrm{AlCl}_{3}$.hour increase the rate decomposition of aluminium chloride. By that the aluminium chloride is decomposed on $86,1 \%$.

Conclusion

1. Water-alkaline procssing of alkylate is replaced by "dry" purification alkylate by solid sorbents.

2. The method "dry" purification of a lkylate with solid sorbent have been developed. 
3. Regeneration of adsorbents consist in hydrolysis of aluminium chloride by over-heated water steam and oxidative regeneration, by that the burning-out of organic residues and dehydration of hydrolysis products take place.

4. Development of the process regeneration of solid sorbents used for purification from containing in it aluminium chloride, hydrochlride and heavy oranic products will allow to improve the process alkylation by use of aluminium chloride as catalyst.

\section{References / Список литературы}

1 Muqanlinski F.F., Sadikhov F.M., Shahverdiyeva F.M., Isayeva N.Y. Purification by solid sorbents. Scientific notes. ASOA. № 3, 1994.

2 Shahverdiyeva F.M., Sadikhov F.M., Salimova N.A. Ecological technologies, purification of alkylate by natural zeolites. Journal "Engineering ecology”. № 2, 2006 Issue "Engineering ecology”. Moscow. Russian Federation.

3 Keltsev N.V. Base of adsorption technique. Publishing house. M. "Chemistry”, 1984. P. 593. 